\title{
Phenytoin-induced increase in growth hormone response to levodopa in adult males
}

\author{
R D'ALESSANDRO, , P CORTELLI, ${ }^{*}$ R GALLASSI, ${ }^{*}$ E GHISOLI, $¥$ N MONTANARO, $\dagger$ \\ E ZONI, ${ }^{*}$ A BARUZZI* \\ From the Institutes of Clinical Neurology* and Pharmacology, $\dagger$ University of Bologna, and the Bentivoglio \\ Hospital, $\ddagger$ Bologna, Italy
}

SUMMARY Growth hormone and prolactin response to levodopa were evaluated before and after long-term phenytoin treatment in five men with previously untreated partial epilepsy. After phenytoin treatment, growth hormone response to levodopa increased. There was a close relationship between growth hormone response to levodopa and plasma phenytoin concentrations. These findings suggest a phenytoin-induced dopaminergic activity at the hypothalamic-pituitary level in adult males.

Recently, Luoma et al ${ }^{1}$ reported elevated serum growth hormone $(\mathrm{GH})$ levels in women treated with phenytoin and carbamazepine. London et al, however, reported lowered response of growth hormone to insulin hypoglycaemia, unchanged baseline growth hormone levels, and increased prolactin response to thyrotropin-releasing hormone administration in healthy male volunteers after 7 days of treatment with phenytoin or carbamazepine. Such hormonal changes may be due to interaction of phenytoin or carbamazepine with the monaminergic systems that control hypothalamic-pituitary function. ${ }^{3}$

Clinical findings indirectly suggest that phenytoin may interact with the dopaminergic system at the striatal level. ${ }^{4}$ Furthermore, both in vivo and in vitro laboratory studies indicate that phenytoin changes the dopaminergic activity within the central nervous system. Hadfield ${ }^{5}$ showed that dopamine uptake is inhibited by phenytoin in the striatum but stimulated in the hypothalamus; Elliott $e^{a} a^{6}$ found that phenytoin reduced dopamine utilisation and induced a neuroleptic-like activity in behavioral tests on mice. Lepore $e t a l^{\prime}$ suggested that phenytoin may act as a dopaminergic agonist, since it reduces dopamine turnover in rat striatum.

In the present study, we evaluated growth hormone and prolactin response to levodopa in epilep-

Address for reprint request: $\operatorname{Dr} \mathbf{R}$ D'Alessandro, Clinica Neurologica, Via U.Foscolo 7, 40123 Bologna, Italy.

Received 9 August 1983 and in revised form 7 December 1983. Accepted 30 January 1984 tic men before and after long-term administration of phenytoin to determine if the treatment had any effect on hypothalamic-pituitary regulation.

\section{Subjects and methods}

The study was performed on five epileptic men (22 to 49 years of age) who had less than a 6 month history of previously untreated cryptogenetic partial epilepsy. All patients gave their informed consent to the study. The levodopa test was performed both before and after 1 month of phenytoin treatment.

The levodopa test always started at $8.00 \mathrm{am}$, after a whole night fast and a $30 \mathrm{~min}$ rest period, and was performed as follows: a 21-gauge scalpvein needle was inserted into a anticubital vein and patency was achieved by a slow drip of physiological saline. Blood samples were taken $15 \mathrm{~min}$ before $(-15)$, immediately before $(0)$, and $30,60,90,120$, and $180 \mathrm{~min}$ after oral administration of $500 \mathrm{mg}$ of levodopa, Blood samples, collected in test tubes containing EDTA, were promptly centrifuged and the plasma aliquot was divided into two parts and stored at $-20^{\circ} \mathrm{C}$ for hormone analysis and drug concentration determinations.

Plasma prolactin and growth hormone concentrations were determined in duplicate by radioimmunoassay, using a commercially available kit (Biodata, Serono, Italy). The method is sensitive to $1.0 \mathrm{ng} / \mathrm{ml}$. for prolactin and $0.25 \mathrm{ng} / \mathrm{ml}$ for growth hormone. Plasma phenytoin concentrations were measured by a gas chromatographic method. ${ }^{8}$

In two patients, the oral dose of phenytoin was increased on the basis of low plasma phenytoin concentrations, and the levodopa test was repeated after 1 month. Thereafter, phenytoin was further increased in one patient and the levodopa test was repeated again 1 month later. (For these two patients, the data reported in tables 1 and 2 refer to 
the levodopa test obtained at the higher plasma phenytoin concentrations).

\section{Statistical analysis}

Serum prolactin and growth hormone concentration values $(\mathrm{ng} / \mathrm{ml})$ underwent two separate analyses of variance (ANOVA) according to a $2 \times 7 \times 5$ design (phenytoin $\times$ times of levodopa administration $\times$ subjects). Data were submitted to log-transformation in order to achieve the condition of homogeneity of "error" variances. If the interaction "phenytoin treatment $\times$ times of levodopa administration" was significant, ANOVA was followed by single contrasts "before vs after phenytoin" at each of the seven times of the levodopa test.9 Further, the relationship between plasma phenytoin levels and growth hormone peak response to levodopa was evaluated by linear regression analysis. The analysis was performed on the differences between the peak growth hormone value obtained before and after antiepileptic drug treatment; eight differences were evaluated since two of the five subjects had more than one test.

\section{Results}

\section{GROWTH HORMONE RESPONSE TO LEVODOPA TEST}

Table 1 shows the individual values obtained at each of the seven levodopa test times before and after 1 month of phenytoin treatment; the table also contains the mean $( \pm S E M)$ on the original scale (ng/ $\mathrm{ml}$ ). ANOVA of log-transformed values yielded a highly significant interaction "phenytoin treatment $x$ times of levodopa test" $(F=3 \cdot 296 ; D F=6 / 52$; $\mathrm{p}<0.01$ ), indicating that growth hormone response exhibited a different trend after phenytoin treatment. Single "before vs after" contrasts (see Table 1) showed no differences at test times -15 and 0 (unchanged baseline values), whereas significantly higher mean values were seen at 60,90 and $120 \mathrm{~min}$ after levodopa administration in comparison with the respective values obtained before anticonvulsant therapy.

Linear regression analysis (fig) showed a highly significant correlation between peak growth hormone changes and plasma phenytoin concentrations $(r=0.96 ; F=69.82 ; D F=1 / 6 ; p<0.001)$.

\section{PROLACTIN RESPONSE TO LEVODOPA TEST}

Table 2 shows the single values obtained from the observations as well as the means ( \pm SEM) on the original scale $(\mathrm{ng} / \mathrm{ml})$. As in growth hormone response, ANOVA of log-transformed values yielded a significant interaction "phenytoin treatment $\times$ times of levodopa test" $(F=2 \cdot 766 ; D F=$ $6 / 52 ; p<0.025)$, indicating that prolactin response to levodopa also displayed a different pattern after phenytoin treatment. In this case, too, "before vs after" contrasts (see table 2) did not show any difference in baseline values at -15 and 0 test times, but revealed changes in the response to dopaminergic stimulation after phenytoin therapy. The mean prolactin values were lower at 120 and 180 min after levodopa administration.

\section{Discussion}

Our study showed that chronic phenytoin administration enhanced growth hormone and prolactin responses to levodopa. However the effect of phenytoin on prolactin response, although statistically significant, must be considered with caution since the magnitude of the differences in prolactin levels

Table 1 Plasma growth hormone concentration in response to administration of $500 \mathrm{mg}$ of levodopa before (B) and after (A) phenytoin treatment

\begin{tabular}{|c|c|c|c|c|c|c|c|c|}
\hline \multirow[t]{2}{*}{ Patients } & \multicolumn{7}{|c|}{ Plasma growth hormone concentration $(\mathrm{ng} / \mathrm{ml})$} & \multirow[b]{2}{*}{$\begin{array}{l}\text { Min } 180 \\
\text { levodopa }\end{array}$} \\
\hline & & $\begin{array}{l}\text { Min - } 15 \\
\text { levodopa }\end{array}$ & $\begin{array}{l}\text { Min O } \\
\text { levodopa }\end{array}$ & $\begin{array}{l}\text { Min } 30 \\
\text { levodopa }\end{array}$ & $\begin{array}{l}\text { Min } 60 \\
\text { levodopa }\end{array}$ & $\begin{array}{l}\text { Min } 90 \\
\text { levodopa }\end{array}$ & $\begin{array}{l}\text { Min } 120 \\
\text { levodopa }\end{array}$ & \\
\hline 1 & $\begin{array}{l}\mathbf{B} \\
\mathbf{A}\end{array}$ & $\begin{array}{l}0.95 \\
1 \cdot 20\end{array}$ & $\begin{array}{l}0.08 \\
1 \cdot 10\end{array}$ & $\begin{array}{r}6 \cdot 00 \\
16 \cdot 00\end{array}$ & $\begin{array}{l}18 \cdot 00 \\
42 \cdot 00\end{array}$ & $\begin{array}{r}3.80 \\
30 \cdot 00\end{array}$ & $\begin{array}{l}1 \cdot 90 \\
7 \cdot 00\end{array}$ & $\begin{array}{l}1 \cdot 00 \\
1 \cdot 90\end{array}$ \\
\hline 2 & $\begin{array}{l}\mathbf{B} \\
\mathbf{A}\end{array}$ & $\begin{array}{l}0.36 \\
0.48\end{array}$ & $\begin{array}{l}0.30 \\
0.38\end{array}$ & $\begin{array}{l}0.40 \\
0.60\end{array}$ & $\begin{array}{l}0.40 \\
5 \cdot 00\end{array}$ & $\begin{array}{r}0.46 \\
27.00\end{array}$ & $\begin{array}{l}0.50 \\
9 \cdot 00\end{array}$ & $\begin{array}{l}0.65 \\
0.60\end{array}$ \\
\hline 3 & $\begin{array}{l}\mathbf{B} \\
\mathbf{A}\end{array}$ & $\begin{array}{l}1 \cdot 20 \\
0.42\end{array}$ & $\begin{array}{l}1 \cdot 00 \\
0.38\end{array}$ & $\begin{array}{l}2.80 \\
0.65\end{array}$ & $\begin{array}{l}1 \cdot 50 \\
8 \cdot 50\end{array}$ & $\begin{array}{l}1 \cdot 00 \\
5 \cdot 60\end{array}$ & $\begin{array}{l}1 \cdot 10 \\
2 \cdot 60\end{array}$ & $\begin{array}{l}1.00 \\
0.65\end{array}$ \\
\hline 4 & $\begin{array}{l}\mathbf{B} \\
\mathbf{A}\end{array}$ & $\begin{array}{l}0.55 \\
0.82\end{array}$ & $\begin{array}{l}0.95 \\
0.48\end{array}$ & $\begin{array}{r}2 \cdot 90 \\
15 \cdot 00\end{array}$ & $\begin{array}{r}3.90 \\
16 \cdot 00\end{array}$ & $\begin{array}{l}0.95 \\
1.35\end{array}$ & $\begin{array}{l}0.70 \\
0.75\end{array}$ & $\begin{array}{l}0.57 \\
0.48\end{array}$ \\
\hline 5 & $\begin{array}{l}\mathbf{B} \\
\mathbf{A}\end{array}$ & $\begin{array}{l}0.85 \\
0.70\end{array}$ & $\begin{array}{l}0.90 \\
0.82\end{array}$ & $\begin{array}{l}0.82 \\
1.00\end{array}$ & $\begin{array}{l}0.80 \\
2.50\end{array}$ & $\begin{array}{l}0.85 \\
7.80\end{array}$ & $\begin{array}{l}0.70 \\
3.00\end{array}$ & $\begin{array}{l}0.82 \\
0.90\end{array}$ \\
\hline $\begin{array}{l}\text { B Mean ( } \pm \text { SEM) } \\
\text { A Mean ( } \pm \text { SEM }) \\
\text { B vs A* } \\
\text { "From ANOVA o }\end{array}$ & & $\begin{array}{l}0.78 \pm 0.15 \\
0.72 \pm 0.14 \\
\text { NS } \\
\text { ansformed val }\end{array}$ & $\begin{array}{l}0.79 \pm 0.13 \\
0.63 \pm 0.14 \\
\text { NS }\end{array}$ & $\begin{array}{l}2.58 \pm 0.99 \\
6.65 \pm 3.62 \\
\text { NS }\end{array}$ & $\begin{array}{l}4.92 \pm 3.32 \\
14 \cdot 80 \pm 7 \cdot 17 \\
p<0.005\end{array}$ & $\begin{array}{l}1.41 \pm 0.60 \\
14.35 \pm 5.89 \\
p<0.0001\end{array}$ & $\begin{array}{l}0.98 \pm 0.25 \\
4.47 \pm 1.52 \\
p<0.02\end{array}$ & $\begin{array}{l}0.81 \pm 0.09 \\
0.91 \pm 0.03 \\
\text { NS }\end{array}$ \\
\hline
\end{tabular}




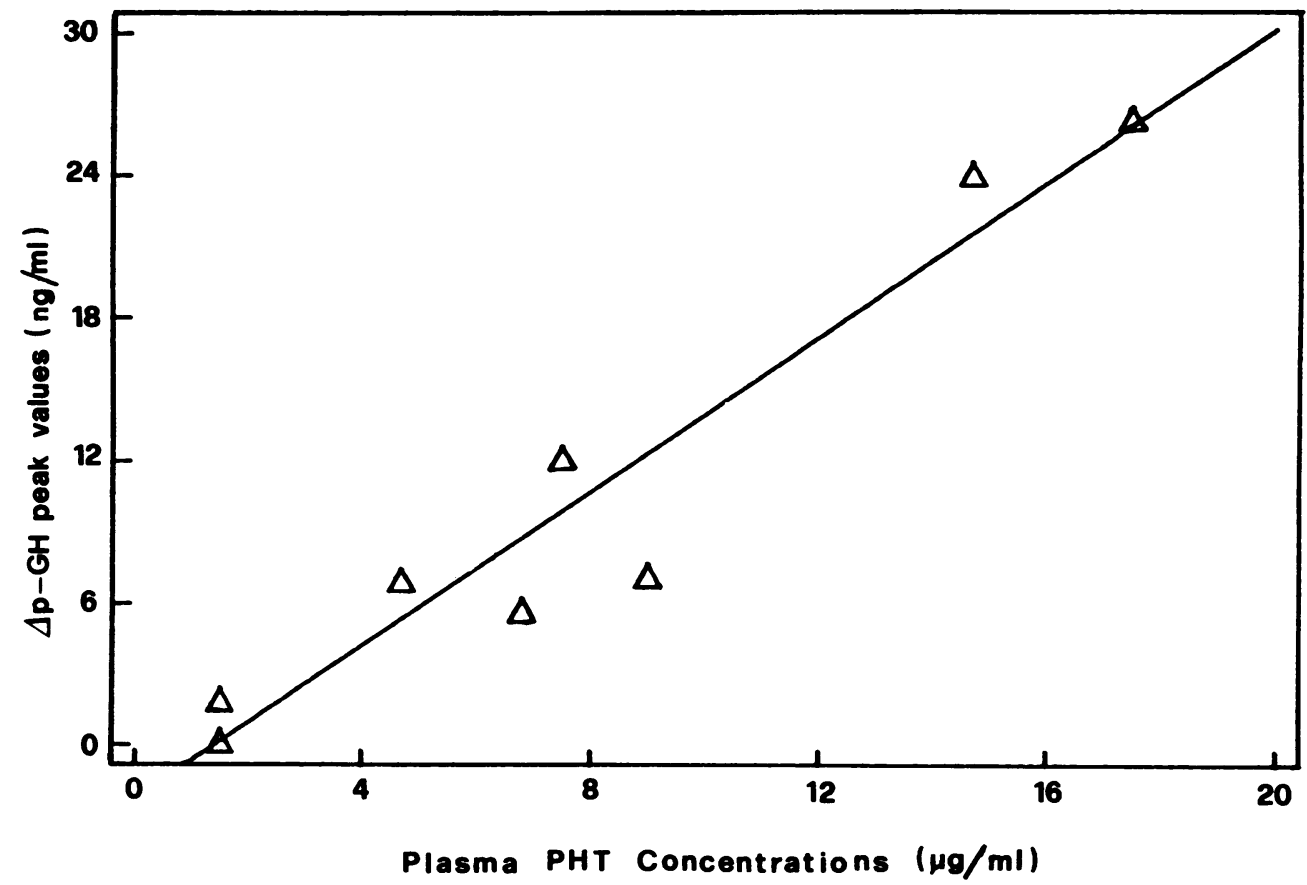

Fig Linear regression of peak growth hormone changes on plasma phenytoin concentrations. Peak growth hormone changes were calculated as differences $(\Delta p)$ between peak growth hormone response to levodopa before and after phenytoin treatment.

before and after phenytoin treatment does not exceed the range of error of the assay. Secretion of growth hormone and prolactin is controlled by monoaminergic pathways in the hypothalamicinfundibular region. Growth hormone secretion is increased by dopaminergic, adrenergic, and serotoninergic activity, ${ }^{10-12}$ whereas prolactin secretion is increased by serotoninergic but inhibited by dopaminergic activity. ${ }^{13-16}$ Hormonal changes reported by other authors, both in baseline values ${ }^{1}$

Table 2 Plasma prolactin concentration in response to administration of $500 \mathrm{mg}$ of levodopa before $(B)$ and after $(A)$ phenytoin treatment

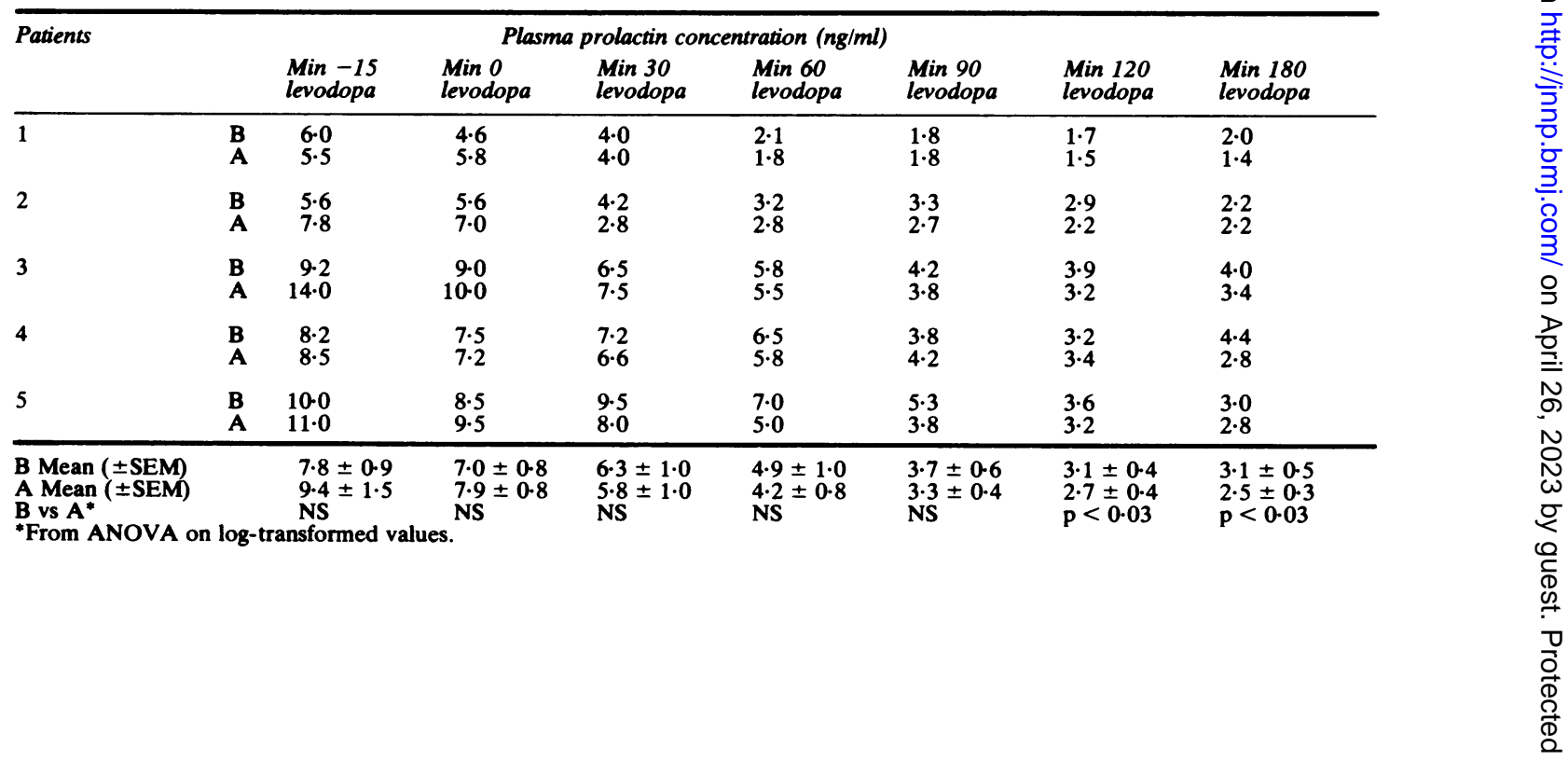


and under stimulation tests, ${ }^{2}$ may be due to an interaction of phenytoin with these monoaminergic systems. Levodopa may act on growth hormone secretion by increasing both dopaminergic and adrenergic activity. ${ }^{1012}$ However, clinical ${ }^{4}$ and laboratory studies ${ }^{5-7}$ indicate dopaminergic activity of phenytoin. Moreover, prolactin changes induced by levodopa in our study, although cautiously interpreted, are consistent with a dopaminergic effect of phenytoin. On this basis we believe that the increased growth hormone response to levodopa after phenytoin administration is mainly due to a dopaminergic effect.

Mendez et al. ${ }^{17}$ reported that phenytoin worsens the symptoms of patients with Parkinson's disease who are treated with levodopa and of patients with Huntington's chorea. In Huntington's chorea, hypersensitivity to dopamine of neurons in the caudate nucleus has been suggested as a primary defect. ${ }^{18-20}$ The worsening of Huntington's chorea, as well as mental agitation, supports the hypothesis of a dopaminergic effect of phenytoin, whereas the worsening of Parkinson's disease is probably due to increased levodopa metabolism caused by liver enzyme induction associated with phenytoin administration, as suggested by Lühdorf and Lund. ${ }^{4}$ Previously, London et al ${ }^{2}$ reported diminished growth hormone response to insulin hypoglycaemia after phenytoin treatment, but phenytoin was administered for only 7 days and reached plasma concentrations of less than $1 \mu \mathrm{g} / \mathrm{ml}$. Furthermore, the insulin hypoglycaemia test is not as specific as the levodopa test because it modifies the activity of systems other than the dopaminergic one. ${ }^{1021}$ Therefore, our findings are not directly comparable with those of London et al. ${ }^{2}$

Our study supports, as regards hypothalamicpituitary function, previous findings indicating a dopaminergic effect of phenytoin. ${ }^{4-7}$ Such dopaminergic effect may play a specific therapeutic role in some possibly dopamine-related types of reflex epilepsy; ${ }^{22}$ it also may explain human hyperkinesias during phenytoin therapy. ${ }^{4}$ The mechanism by which phenytoin may have dopaminergic activity is uncertain.

Phenytoin has an inhibitory effect on the $\mathrm{Ca}^{++}$ calmodulin complex, ${ }^{23}$ which could affect the activity or sensitivity of dopamine receptors. ${ }^{24}$ Acting on the $\mathrm{Ca}^{++}$-calmodulin complex, phenytoin may enhance dopamine receptor responsiveness.

Further studies are necessary to assess the dopaminergic effect of phenytoin and to evaluate its clinical implications.

\section{References}

' Luoma PV, Myllylä VV, Hokkanen E. Elevated serum growth hormone levels in patients treated with anticonvulsants. In: Canger R, Angeleri F, Penry JK, eds. Advances in Epileptology: XIth Epilepsy International Symposium. New York: Raven Press, 1980;431-3.

${ }^{2}$ London DR, Loizou LA, Butt WR, Rovei V, Bianchetti $G$, Morselli PL. The effect of anticonvulsant drugs (AED) on hormonal responses in normal volunteers. In: Johannessen et al., eds. Antiepileptic Therapy: Advances in Drug Monitoring; New York: Raven Press, 1980;405-11.

${ }^{3}$ Martin JB, Reichlin S, Brown GM. Hypothalamic control of anterior pituitary secretion. In: Plum F, McDowell FH, eds. Clinical Neuroendocrinology. Philadelphia: FA Davis, 1977; 13-44.

${ }^{4}$ Lühdorf K, Lund M. Phenytoin-induced hyperkinesia. Epilepsia 1977;18:409-15.

5 Hadfield MG. Uptake and binding of catecholamines. Effect of diphenylhydantoin and new mechanism of action. Arch Neurol 1972; 26:78-84.

- Elliott PN, Jenner P, Chadwick D, Reynolds E, Marsden CD. The effect of diphenylhydantoin on central catecholamine containing neuronal systems. J Pharm Pharmacol 1977;29:41-43.

${ }^{7}$ Lepore V, Di Reda N, Pedone D, Lanzi C, La Montanara D, Livrea P. Livelli di acido omovanillico nello striato di ratto: effetto di difenilidantoina ed interazione con haloperidol ed apomorfina. Boll Lega Ital Epil 1982;39 suppl:61.

${ }^{8}$ Riva R, Albani F, Baruzzi A. Rapid quantitative determination of underivatized carbamazepine, phenytoin, phenobarbital and hydroxyphenobarbital in biological fluids by packed column gas chromatography. $J$ Chromatogr 1980;221:75-84.

9 Winer BJ. Statistical Principles in Experimental Design. 2nd ed, New York: McGraw-Hill Book Co., 1971. Chaps. 5 and 6.

${ }^{10}$ Boyd AE, Lebovitz HE, Pfeiffer JB. Stimulation of human growth-hormone secretion by levodopa. $N$ Engl J Med 1970;283:1425-9.

"Imura H, Nakai Y, Yoshimi T. Effect of 5-hydroxytryptophan (5-HTP) on growth hormone and ACTH release in man. J Clin Endocrinol Metab 1973;36:204-6.

12 Martin JB. Neural regulation of growth hormone secretion. Medical Progress Report. N Engl J Med 1973; 288: 1384-93.

${ }^{13}$ Kleinberg DL, Noel GL, Frantz AG. Chlorpromazine stimulation and levodopa suppression of plasma prolactin in man. $J$ Clin Endocrinol Metab 1971;33:873-6.

${ }^{14}$ Meites J. Recent studies on functions and control of prolactin secretion in rats. Recent Progr Horm Res 1972; 28:471-526.

is Kamberi IA, Mical RS, Porter JC. Effect of anterior pituitary perfusion and intraventricular injection of catecholamines on prolactin release. Endocrinology 1971;88:1012-20.

${ }^{16}$ Martin JB. Inhibition by apomorphine of prolactin secretion in patients with elevated serum prolactin. $J$ Clin Endocrinol Metab 1974;39:180-2.

17 Mendez SJ, Cotzias GL, Mena I, Papavasiliou PS. Diphenylhydantoin blocking of levodopa effects. Arch 
Neurol 1975;32:44-6.

18 Anden NE. Pharmacological and anatomical implications of induced abnormal movements with levodopa. In: Barbeau A, McDowell FH, eds. Levodopa and Parkinsonism. Philadelphia: FA Davies Co, $1970 ; 132-43$.

${ }^{19}$ Klawans HL, Paulson GW, Ringel SP. Use of levodopa in the detection of presymptomatic Huntington's chorea. N Engl J Med 1972;286:1332-4.

${ }^{20}$ Klawans HR Jr. A pharmacologic analysis of Huntington's chorea. Eur Neurol 1970;4:148-63.

${ }^{21}$ Reichlin S. Regulation of somatotrophic hormone secretion. In: Greer RO, Astwood EB, eds. Handbook of Physiology, section 7: Endocrinology, vol. 4, part 2, American Physiological Society. Baltimore: Williams \& Wilkins, 1975;405-47.
22 Anlezark G, Marrosu F, Meldrum B. Dopamine agonists in reflex epilepsy. In: Morselli PL, Lloyd $\mathrm{K}$, Loscher W, Meldrum B, Reynolds E, eds. Neurotransmitters, Seizures, and Epilepsy. New York: Raven Press, $1981 ; 251-60$.

${ }^{23}$ Costa E. Intraneuronal translocation of modulators: a regulatory mechanism for interneuronal communication. In: Gessa GL, Corsini GU, eds. Apomorphine and Other Dopaminomimetics. New York: Raven Press, 1980;143-5.

${ }^{24}$ De Lorenzo RJ. Phenytoin: calcium and calmodulindependent protein phosphorylation and neurotrasmitters release. In: Glaser GH, Penry JK, Woodbury DM, eds. Antiepileptic Drugs: Mechanisms of Action. New York: Raven Press, 1980;399-414. 